\title{
Proyeksi dan Pemetaan Sebaran Kasus Demam Berdarah Dengue (DBD) Berbasis Sistem Informasi Geografi (SIG)
}

\section{Projection and Mapping of Dengue Hemorrhagic Fever (DHF) Cases Based on Geographic Information System (SIG)}

\begin{abstract}
Agung Sutriyawan*1, Ratna Dian Kurniawati ${ }^{2}$, Suherdin ${ }^{3}$
1,2,3Program Studi S1 Kesehatan Masyarakat, Fakultas Ilmu Kesehatan, Universitas Bhakti Kencana, Bandung e-mail: *agung.sutriawan@bku.ac.id, ratna.dian@bku.ac.id, Suherdin@bku.ac.id

Abstrak

Dengue merupakan penyakit tropis yang masih menjadi masalah internasional dalam kesehatan masyarakat di beberapa dekade terakhir. Bandung merupakan Kota yang endemis demam berdarah dengue. Jumlah kasus demam berdarah dengue di Kota Bandung tidak hanya menagalami peningkatan tetapi juga menyebabkan beberapa kematian. Tujuan penelitian ini adalah untuk melakukan proyeksi jumlah kasus demam berdarah dengue dan memberi informasi wilayah sebaran penyakit demam berdarah dengue di Kota Bandung. Riset ini menggunakan metode kuantitatif untuk menganalisis data statistik yaitu data trend perkembangan kasus demam berdarah dengue di Kota Bandung, selama beberapa tahun terakhir (data runut), selanjutnya melakukan proyeksi dengan membaca trend data demam berdarah dengue, menggunakan alat analisis eksponential smothing dengan model holt's linear trend. Selain itu pemetan berdasarkan tempat sebagai data spasial kemudian disajikan dalam bentuk peta sebagai informasi. Hasil penelitian menunjukan bahwa proyeksi jumlah kasus demam berdarah dengue di Kota Bandung pada periode 2021-2025 menggunakan metode microsoft excel mengalami penurunan sedangkan mengunakan metode exponential smoothing model holt's linear trend mengalami peningkatan. Berdasarkan data sekunder kasus demam berdarah dengue, maka pemetaan wilayah persebaran kasus demam berdarah dengue dilakukan di 30 Kecamatan Kota Bandung, terdapat dua Kecamatan dengan jumlah kasus sangat tinggi yaitu Kecamatan Coblong dan Buah Batu. Perlu dilakukan pencegahan kasus demam berdarah dengue di seluruh wilayah Kota Bandung, karena setiap kecamatan yang ada di Kota Bandung berpotensi mengalami peningkatan jumlah kasus di 5 tahun kedepan.
\end{abstract}

Kata kunci: Proyeksi dan pemetaan, DBD, eksponential smoothing, sistem informasi geografi

\section{Abstract}

Dengue is a tropical disease that has remained an international problem in public health in recent decades. Bandung is an endemic city of dengue fever. The number of dengue fever cases in Bandung has not only increased but also caused several deaths. The purpose of this study is to project the number of dengue fever cases and inform the area of dengue fever spread in Bandung. This research uses quantitative method to analyze statistical data, namely trend data on the development of dengue fever cases in Bandung, over the last few years (runut data), then do projections by reading the trend of dengue fever data, using exponential smothing analysis tools with holt's linear trend model. In addition, the pemetan based on the place as spatial data is then presented in the form of map as information. The results showed that the projected number of dengue fever cases in The City of Bandung in the period 2021-2025 using microsoft excel method decreased while using exponential smoothing method holt's linear trend model increased. Based on secondary data of dengue fever cases, the mapping of dengue fever cases is mapping in 30 districts of Bandung, there are two sub-districts with a very high number of cases, namely Coblong and Buah Batu subdistricts. It is necessary to prevent dengue fever cases throughout the city of Bandung, because every sub-district in the city of Bandung has the potential to increase the number of cases in the next 5 years

Keywords: Projection and mapping, DHF, exponential smoothing, geography information system

\section{Pendahuluan}

Dengue merupakan penyakit tropis yang masih menjadi masalah internasional dalam kesehatan masyarakat di beberapa dekade terakhir. ${ }^{1}$ Beberapa tahun terakhir, sekitar 50 juta infeksi virus dengue (DBD) terjadi dan sekitar setengah juta orang terjangkit dengue parah, menyebabkan morbiditas dan mortalitas yang signifikan di seluruh dunia. ${ }^{2}$ Tahun 2020, DBD terus menyerang beberapa negara, dengan laporan peningkatan jumlah kasus di beberapa negara termasuk Indonesia. ${ }^{3}$ Kasus DBD yang 
dilaporkan pada tahun 2019 tercatat sebanyak 138.127 kasus. Jumlah ini meningkat dibandingkan tahun 2018 sebesar 65.602 kasus. Kematian karena DBD pada tahun 2019 juga mengalami peningkatan dibandingkan tahun 2018 yaitu dari 467 menjadi 919 kematian, ${ }^{4}$ sedangkan hingga juli 2020 mencapai 71.633 kasus. 10 Provinsi yang melaporkan jumlah kasus terbanyak ada di Jawa Barat 10.772 kasus. $^{5}$

Penelitian Aris Munandar dan Zalfie Ardian menganalisis sebaran kejadian DBD menggunakan SIG di Kota Banda Aceh, penelitian ini menggunakan metode Rapid Application Development (RAD), menggunakan Sistem Informasi Geografi (SIG) untuk melihat sebaran kejadian DBD di Kota Banda Aceh. ${ }^{7}$ Penelitian lain yang dilakukan Novratilova dan Kusnanto menganalisis sebaran kajadian DBD di Kabupaten Sleman, Yogyakarta. Penelitian ini menganalisa autokorelasi dan Model Geographically Weighted Regression (GWR) berdasarkan data sekunder dari dinas kesehatan Kabupaten Sleman. ${ }^{8}$ Penelitian Faldy, menganalisis sebaran kejadian DBD berdasarkan kecamatan di Kabupaten Minahasa Utara. Penelitian ini menggunakan data primer, dengan jumlah sampel sebanyak 100 responden. ${ }^{9}$ Penelitian Musfanto, dkk menggunakan data skunder untuk melihat sebaran kejadian DBD berdasarkan Kecamatan di Kota Manado. ${ }^{10}$

Penyakit menular khususnya DBD erat hubungan dengan aspek geografi/spasial karena salah satu sumber terjadinya penyakit tidak lepas dari faktor lingkungan. Maka dengan ini faktor lingkungan tersebut dapat dipetakan. Pengambilan keputusan dibidang kesehatan dapat ditunjang dengan informasi dalam bentuk spasial. Kemajuan dalam sistem informasi geografi telah banyak memberikan kontribusi analisis yang lebih efektif dari berbagai aspek sistem kesehatan. SIG merupakan teknologi spasial yang sangat berguna di bidang pengolahan dan perencanaan pemberantasan penyakit menular pada saat ini, termasuk analisis penyakit epidemik seperti DBD. Dengan perangkat SIG, gambaran keruangan (spasial) penyebaran penyakit DBD di permukaan bumi dapat ditampilkan dalam bentuk grafis digital dan dapat divisualisasikan dalam bentuk peta. ${ }^{11}$

Kota Bandung sendiri merupakan salah satu Kota yang endemik DBD. Jumlah kasus DBD di Kota Bandung tidak hanya menagalami peningkatan tetapi juga menyebabkan beberapa kematian. Tahun 2018 jumlah kasus sebanyak 2.826 dengan kematian 7 orang. Terjadi peningkatan yang signifikan ditahuhn 2019 menjadi 4.424 kasus dengan jumlah kematian sebanyak 14 orang. jumlah kasus tertinggi ditahun 2019 ada dibeberapa kecamatan, yaitu: Kiaracondong, Coblong dan Arcamanik. ${ }^{6}$ Maka, dibutuhkan sistem pemetaan berbasis SIG untuk melihat penyebaran kasus DBD pada setiap kecamatan di Kota Bandung agar dapat dilakukan penanganan dan tindakan preventif terhadap kasus DBD. Teknik peramalan dapat dilakukan dari cara yang sederhana hingga dengan cara yang paling kompleks. Dengan digunakannya aplikasi SIG, sehingga dapat menjawab beberapa pertanyaan seperti; lokasi, kondisi, trend, pola dan pemodelan, hal inilah yang membedakan SIG dengan sistem informasi lainnya. ${ }^{12}$

Berdasarkan data dan studi literasi yang digunakan dalam penelitian ini, maka dalam mendukung kebijakan pemerintah terkait one map policy, sebaiknya riset terkait DBD dilakukan dalam bentuk pemodelan berupa grafis pemetaan (maping), untuk memudahkan kita membaca secara kewilayahan dan keruangan (spatial). Penelitian yang akan dilakukan akan lebih berfokus pada sebaran kejadian DBD di Kota Bandung, kemudian akan memproyeksikan jumlah kasus guna melihat trand kejadian DBD di tahun mendatang. Secara umum, riset ini bertujuan untuk melakukan proyeksi jumlah kasus DBD dan memberi informasi wilayah sebaran penyakit DBD di Kota Bandung.

\section{Metode Penelitian}

Penelitian ini menggunakan penelitian kuantitatif deksriptif, diamana peneliti berusaha menjelaskan status dan lokus penelitiannya. ${ }^{13}$ Pendekatan kuantitatif dengan alat analisis exponential 
smoothing, bertujuan untuk melakukan forecasting atau proyeksi terhadap perkembangan kasus DBD di Kota Bndung. Metode Exponential Smoothing merupakan prosedur perbaikan secara terus menerus pada proyeksi terhadap objek pengamatan terbaru. Exponential Smoothing, sering disebut dengan perataan exponential atau penghalusan exponential rata-rata, untuk mengetahui atau meramalkan prokeksi tahun yang akan datang, maka rumus yang sering digunakan sebagai berikut. ${ }^{14}$

$$
\mathbf{F t}+\mathbf{1}=\mathbf{F t}+\alpha(\mathbf{Y t}-\mathbf{F t})
$$

Dimana :

$\mathrm{Ft}+1=$ perkiraan baru (untuk periode waktu $\mathrm{t}+1$ )

$\mathrm{Ft} \quad=$ ramalan sebelumnya (untuk periode waktu $\mathrm{t}$ )

$\alpha \quad=$ konstanta perataan $(0 \leq \alpha \leq 1)$

$\mathrm{Yt} \quad=$ Jumlah DBD aktual periode sebelumnya

Estimasi baru merupakan estimasi lama ditambah sebagian hasil dari kesalahan di periode terakhir. Metode exponential smooth yang digunakan pada penelitian ini adalah pendekatan exponential smooth dengan menggunakan software microsoft excel dan Metode exponential smooth dengan model holt's linear trend menggunakan software IBM SPSS statistic 25. Sedangkan untuk pemetaan wilayah sebaran kejadian DBD, maka dilakukan interpretasi data sekunder dalam bentuk tabel, yang bersumber dari Dinas Kesehatan Kota Bandung dalam periode 2017-2020. Selain itu pemetan berdasarkan tempat sebagai data spasial kemudian disajikan dalam bentuk peta (maping) sebagai informasi.

\section{Hasil}

Melakukan kompilasi data sekunder kedalam suatu tabel, kemudian diinterpretasikan menjadi suatu deskripsi informasi, dengan tujuan agar memudahkan siapapun membaca data kejadian DBD di Kota Bandung. Hal ini dilakukan terhadap data jumlah dan persentase kasus DBD yang terjadi periode tahun 2017-2020. Berikut disajikan jumlah kasus DBD dan jumlah kematian selama tahun 2017-2020.

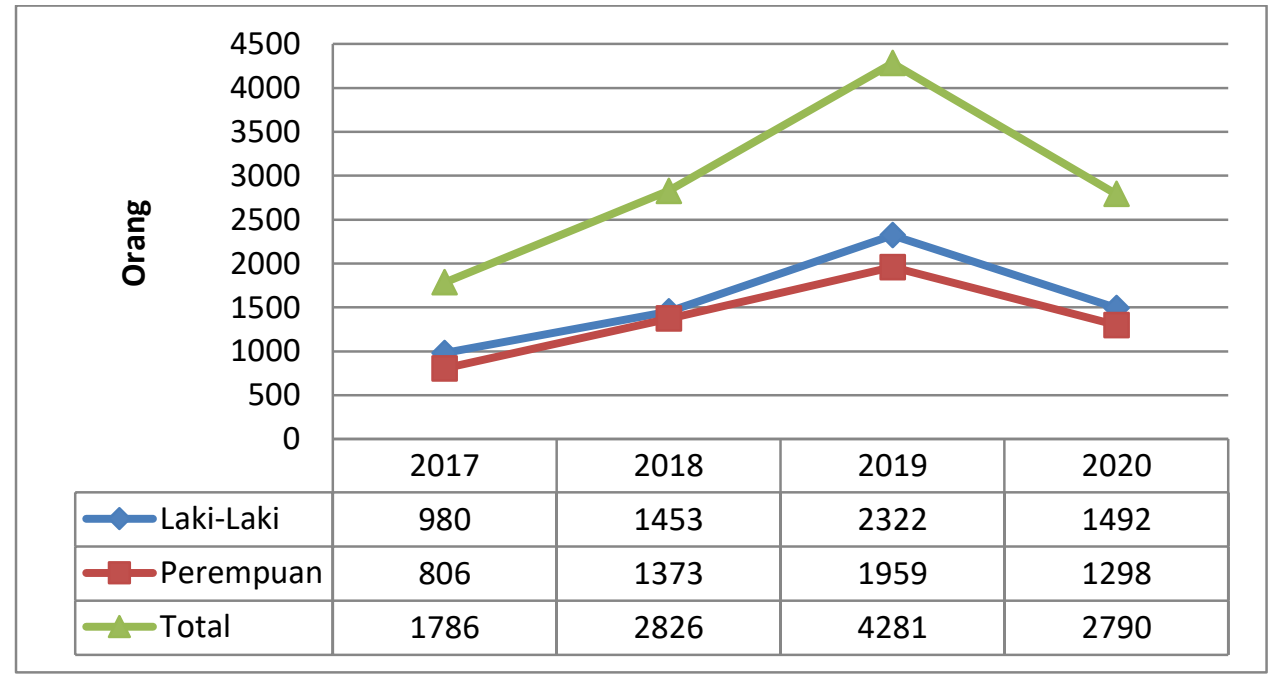

Gambar 1. Grafik Jumlah kasus DBD di Kota Bandung Periode 2017-2020 
Grafik pada gambar 1 menjelaskan bahwa trend kasus DBD di Kota Bandung dalam 4 tahun terakhir mengalami peningkatan dan juga penurunan kasus, dengan kata lain terjadi fluktuasi, terlihat dengan jelas bahwa jumlah kasus DBD pada tahun 2017 sebanyak 1.786 dengan jumlah kasus lebih tinggi pada laki-laki yaitu 54,87\%. Meningkat ditahun 2018 menjadi 2.826 kasus dengan kasus lebih tinggi pada laki-laki yaitu 51,41\%. Meningkat kembali ditahun 2019 menjadi 4.281 kasus dengan kasus lebih tinggi pada laki-laki yaitu 54,24\%. Selanjutnya jumlah kasus DBD mengalami penurunan di tahun 2020 menjadi 2.790 kasus dengan kasus lebih tinggi pada laki-laki yaitu 53,37\%.

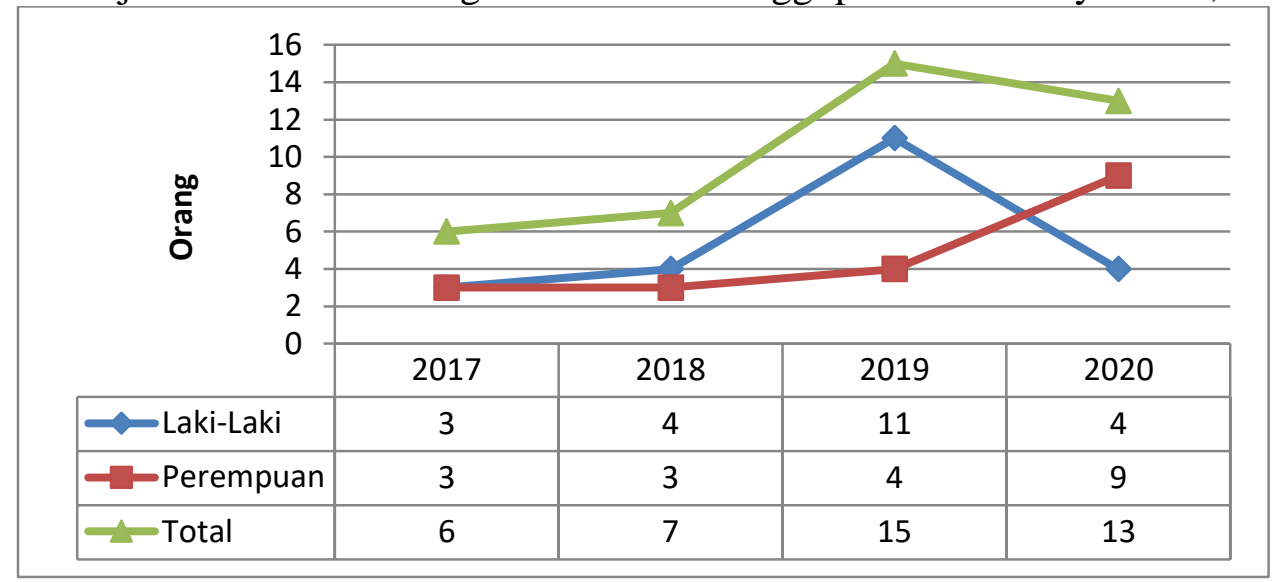

Gambar 2. Grafik Jumlah Kematian DBD di Kota Bandung Periode 2017-2020

Grafik pada gambar 1 menjelaskan bahwa trend kematian akbibat DBD di Kota Bandung selama 4 tahun terakhir mengalami peningkatan dan juga penurunan. Tahun 2017 kematian sebanyak 6 orang terjadi pada 50\% laki-laki dan perempuan. Meningkat di tahun 2018 menjadi 7 kasus dengan kematian tertinggi pada jenis kelamin laki-laki yaitu 57,14\%. Meningkat kembali ditahun 2019 menjadi 15 kasus dengan kematian lebih tinggi pdaa laki-laki yaitu 73,33\%. Kematian akibat DBD sedikit menurun ditahun 2020 yaitu 13 kasus dengan kematian lebih tinggi pada perempuan yaitu $69,23 \%$.

Peramalan atau proyeksi terhadap perkembangan kasus DBD pada periode 2021-2025 dilakukan dengan metode exponential smoothing berbasis microsoft excel. Proses dilakukan dengan menggunakan rumus umum exponential smoothing. Hasil analisis pada micrososft excel menunjukan bahwa terjadi perubahan yang signifikan pada perkembangan kasus DBD di tahun 2025, hasil analisis (peramalan) dapat dilihat pada tabel 2 berikut:

Tabel 1. Hasil Proyeksi Kejadian DBD di Kota Bandung periode 2020-2025

\begin{tabular}{llllll}
\hline Tahun & $\begin{array}{c}\text { Jumlah Kasus } \\
\text { DBD }\end{array}$ & Forecast/ Proyeksi & Error (Deviasi) & MAD (Absolute) & MSE (Squared) \\
\hline 2017 & 1786 & 1786 & 0 & 0 & 0 \\
2018 & 2826 & 1786 & 1040 & 1040 & 1081600 \\
2019 & 4281 & 1838 & 2443 & 2443 & 5968249 \\
2020 & 2790 & 1960 & 829.85 & 829.85 & 688651.02 \\
2021 & & 2002 & -2001.643 & 2001.6425 & 4006572.7 \\
2022 & & 1902 & -1901.56 & 1901.56038 & 3615931.9
\end{tabular}




\begin{tabular}{lllll}
2023 & 1806 & -1806.482 & 1806.48236 & 3263378.5 \\
2024 & 1716 & -1716.158 & 1716.15824 & 2945199.1 \\
2025 & 1630 & -1630.35 & 1630.35033 & 2658042.2 \\
\hline \multicolumn{2}{c}{ Total } & -4743.344 & 4743.3438 & 22499310 \\
\hline Rata-Rata & -1185.836 & 1185.83595 & 5624827.6 \\
\hline SE & & & 3354.0506 \\
\hline
\end{tabular}

Tabel 1 menunjukan bahwa terjadi pergerakan kasus DBD dari tahun 2020 (tahun dasar proyeksi) yaitu sebesar 2.790 kasus, turun menjadi 1.630 kasus (hasil proyeksi) pada tahun 2025 . Terlihat ada selisih 1.160 kasus atau terjadi pengurangan kasus DBD sebanyak 1.160 (41,57\%) kasus. Hal ini menunjukan bahwa ada penurunan jumlah kasus pada periode 2020-2025. Artinya, ada trend posistif dalam perkembangan kasus DBD di Kota Bandung dalam periode 5 tahun kedepan.

Proses peramalan (proyeksi) dengan metode exponential smoothing menggunakan software SPSS statistics 25, bertujuan untuk memprediksi perkembangan kasus stunting pada periode 2020 (tahun dasar) hingga tahun 2025 (tahun proyeksi) atau dengan kata memprediksi jumlah kasus DBD selama 5 tahun kedepan. Selain itu penggunaan metode exponential smoothing berbasis SPSS bertujuan untuk melihat apakah hasi yang diperoleh menggunakan SPSS sama dengan menggunakan microsoft excel atau sebaliknya?, Apakah kecenderungan trendnya sama atau sebaliknya?. Untuk mengetahui dan membaca hasil proyeksi metode exponential smoothing model holt's linear trend berbasis, dapat dilihat pada tabel hasil analisis dan grafik berikut:

Tabel 2. Model Summary

\begin{tabular}{|c|c|c|c|c|c|c|c|c|c|}
\hline \multirow[b]{3}{*}{ Model } & \multicolumn{8}{|c|}{ Model Statistics } & \multirow{3}{*}{$\begin{array}{l}\text { Number } \\
\text { of } \\
\text { Outliers }\end{array}$} \\
\hline & & \multicolumn{4}{|c|}{ Model Fit statistics } & \multicolumn{3}{|c|}{ Ljung-Box Q(18) } & \\
\hline & $\begin{array}{l}\text { Number of } \\
\text { Predictors }\end{array}$ & $\begin{array}{l}\text { Stationary } \\
\text { R-squared }\end{array}$ & $\begin{array}{c}\text { R- } \\
\text { squared }\end{array}$ & RMSE & MAPE & Statistics & DF & Sig. & \\
\hline $\begin{array}{l}\text { Jumlah Kasus } \\
\text { DBD-Model_1 }\end{array}$ & 0 & 5,501 & $\overline{0}, 026$ & 1241,357 & 23,090 & & 0 & & 0 \\
\hline
\end{tabular}

Tabel 3. Forecast Kasus BDB di Kota Bandung Tahun 2021-2025

\begin{tabular}{|c|c|c|c|c|c|c|}
\hline \multicolumn{7}{|c|}{ Forecast } \\
\hline Model & & 2021 & 2022 & 2023 & 2024 & 2025 \\
\hline \multirow{3}{*}{$\begin{array}{l}\text { Jumlah Kasus DBD- } \\
\text { Model_1 }\end{array}$} & Forecast & 3928 & 4375 & 4822 & 5268 & 5715 \\
\hline & UCL & 9270 & 9951 & 10623 & 11286 & 11942 \\
\hline & LCL & -1413 & -1201 & -979 & -749 & -512 \\
\hline
\end{tabular}

Hasil proyeksi pada tabel 4 dengan metode exponential smooth model holt's linear trend, menunjukan ada perbedaan dengan hasil analisis dengan software microsoft excel. Pada hasil proyeksi dengan excel, angka DBD pada tahun 2021 sebesar 2.002 kasus DBD sedangkan menggunakan metode forecasting metode exponential smoothing model holt's linear trend, hasil yang didapatkan adalah 3.928 kasus DBD di tahun 2021. Begitu pula hasil proyeksi tahun 2025, dengan menggunakan microsoft excel, hasil proyeksi yaitu 1.630 kasus DBD, sedangkan menggunakan 
model holt's linear trend hasil yang didapatkan sebesar 5.715 kasus DBD. Hal ini menunjukan ada perbedaan signifikan hasil analisis dengan dua software (aplikasi) yang digunakan dalam proses peramalan (proyeksi). Sedangkan untuk melihat perkembangan atau membaca trend kasus DBD pada periode 2020-2025 dapat dilihat pada gambar 3 berikut:



Gambar 3. Grafik Proyeksi Jumlah Kejadian DBD Periode 2021-2025

Pada gambar 3, grafik menunjukan bahwa terjadi peningkatan signifikan pada jumlah kasus DBD periode 2020-2025. Hasil proyeksi tahun 2021 yaitu 3.928 berada di bawah angka kasus DBD pada tahun 2020 (tahun dasar) yaitu sebesar 2790 kasus. Hasil proyeksi pada tahun 2025 yaitu sebesar 5.715 kasus. Artinya ada trend peningkatan dalam kasus DBD di Kota Bandung dalam 5 tahun kedepan.

Sebelum melakukan pemetaan wilayah sebaran kasus DBD, terlebih dahulu dilakukan olah data dan analisis terhadap data sekunder jumlah kasus DBD di Kota Bandung. Dari 30 Kecamatan yang berada di Kota Bandung. Berikut adalah data jumlah dan sebaran kasus DBD pada 30 kecamatan di Kota Bandung:

Tabel 5. Jumlah dan Persentase Kejadian DBD di Kota Bandung Periode 2017-2020 dalam Sebaran Wilayah Kecamatan

\begin{tabular}{llccccccccc}
\hline & & \multicolumn{8}{c}{ Jumlah Kasus DBD } \\
\cline { 3 - 10 } No & \multirow{2}{*}{ Kecamatan } & \multicolumn{2}{c}{2017} & \multicolumn{2}{c}{2018} & \multicolumn{2}{c}{2019} & \multicolumn{2}{c}{2020} \\
\cline { 3 - 10 } & & Jumlah & $\%$ & Jumlah & $\%$ & Jumlah & $\%$ & Jumlah & $\%$ \\
\hline 1 & Sukasari & 43 & 2.41 & 87 & 3.08 & 176 & 4.11 & 100 & 3.58 \\
2 & Sukajadi & 36 & 2.02 & 95 & 3.36 & 207 & 4.84 & 105 & 3.76 \\
3 & Cicendo & 34 & 1.9 & 93 & 3.29 & 110 & 2.57 & 82 & 2.94 \\
4 & Andir & 33 & 1.85 & 67 & 2.37 & 78 & 1.82 & 84 & 3.01 \\
5 & Cidadap & 12 & 0.67 & 45 & 1.59 & 117 & 2.73 & 60 & 2.15 \\
6 & Coblong & 127 & 7.11 & 187 & 6.62 & 263 & 6.14 & 189 & 6.77 \\
7 & Bandung wetan & 24 & 1.34 & 35 & 1.24 & 62 & 1.45 & 47 & 1.68 \\
8 & Sumur bandung & 25 & 1.4 & 41 & 1.45 & 49 & 1.14 & 59 & 2.11 \\
9 & Cibeunying kaler & 64 & 3.58 & 112 & 3.96 & 125 & 2.92 & 85 & 3.05
\end{tabular}




\begin{tabular}{llcccccccc}
\hline & & \multicolumn{7}{c}{ Jumlah Kasus DBD } \\
\cline { 3 - 9 } No & \multirow{2}{*}{ Kecamatan } & \multicolumn{2}{c}{2017} & \multicolumn{2}{c}{2019} & \multicolumn{2}{c}{2020} \\
\cline { 3 - 9 } & & Jumlah & $\%$ & Jumlah & $\%$ & Jumlah & $\%$ & Jumlah & $\%$ \\
\hline 10 & Cibeunying kidul & 106 & 5.94 & 222 & 7.86 & 206 & 4.81 & 90 & 3.23 \\
11 & Kiaracondong & 114 & 6.38 & 175 & 6.19 & 308 & 7.19 & 111 & 3.98 \\
12 & Batununggal & 131 & 7.33 & 162 & 5.73 & 193 & 4.51 & 131 & 4.70 \\
13 & Lengkong & 138 & 7.73 & 90 & 3.18 & 128 & 2.99 & 97 & 3.48 \\
14 & Regol & 115 & 6.44 & 80 & 2.83 & 120 & 2.80 & 67 & 2.40 \\
15 & Bojongloa kaler & 24 & 1.34 & 89 & 3.15 & 150 & 3.50 & 93 & 3.33 \\
16 & Astana anyar & 58 & 3.25 & 90 & 3.18 & 96 & 2.24 & 66 & 2.37 \\
17 & Bojongloa kidul & 18 & 1.01 & 84 & 2.97 & 114 & 2.66 & 50 & 1.79 \\
18 & Babakan ciparay & 17 & 0.95 & 88 & 3.11 & 130 & 3.04 & 90 & 3.23 \\
19 & Bandung kulon & 25 & 1.4 & 47 & 1.66 & 94 & 2.20 & 64 & 2.29 \\
20 & Antapani & 92 & 5.15 & 128 & 4.53 & 159 & 3.71 & 120 & 4.30 \\
21 & Mandalajati & 33 & 1.85 & 95 & 3.36 & 143 & 3.34 & 87 & 3.12 \\
22 & Arcamanik & 62 & 3.47 & 95 & 3.36 & 241 & 5.63 & 139 & 4.98 \\
23 & Ujung berung & 32 & 1.79 & 81 & 2.87 & 222 & 5.19 & 137 & 4.91 \\
24 & Cinambo & 26 & 1.46 & 24 & 0.85 & 70 & 1.64 & 36 & 1.29 \\
25 & Cibiru & 29 & 1.62 & 105 & 3.72 & 173 & 4.04 & 72 & 2.58 \\
26 & Panyileukan & 34 & 1.9 & 48 & 1.7 & 77 & 1.80 & 77 & 2.76 \\
27 & Gedebage & 29 & 1.62 & 56 & 1.98 & 104 & 2.43 & 64 & 2.29 \\
28 & Rancasari & 89 & 4.98 & 100 & 3.54 & 143 & 3.34 & 143 & 5.13 \\
29 & Buah batu & 134 & 7.5 & 131 & 4.64 & 113 & 2.64 & 180 & 6.45 \\
30 & Bandung kidul & 82 & 4.59 & 74 & 2.62 & 110 & 2.57 & 65 & 2.33 \\
\hline & Kota Bandung & 1786 & 100 & 2826 & 100 & 4281 & 100 & 2790 & 100 \\
\hline
\end{tabular}

Data pada tabel 5 menunjukan bahwa kasus DBD tersebar merata pada 30 Kecamatan di Kota Bandung. Hal ini merupakan informasi statistik yang berguna dalam pengembangan isu DBD di Kota Bandung dan Indonesia secara nasional. Tahun 2017 kasus DBD tertinggi terdapat di Kecamatan Lengkong sebanyak 138 kasus (7,73\%). Tahun 2018 kasus DBD tertinggi terdapat di Kecamatan Cibeunying Kidul sebanyak 222 kasus (7,86\%). Tahun 2019 kasus DBD tertinggi terdapat di Kecamatan Kiaracondong sebanyak 308 kasus (7,19\%).. Pada tahun 2020 kasus DBD tertinggi terdapat di Kecamatan Coblong sebanyak 189 kasus (6,77\%).

Pemetaan wilayah sebaran kasus DBD periode 2017-2020 merupakan bentuk visualisasi data kasus DBD, untuk memberikan informasi dalam bentuk gambar (model). Model atau gambar peta kasus DBD yang tersebar di seluruh wilayah Kota Bandung, disajikan kedalam peta sebaran kasus stunting pada tahun 2020, sebagai berikut: 

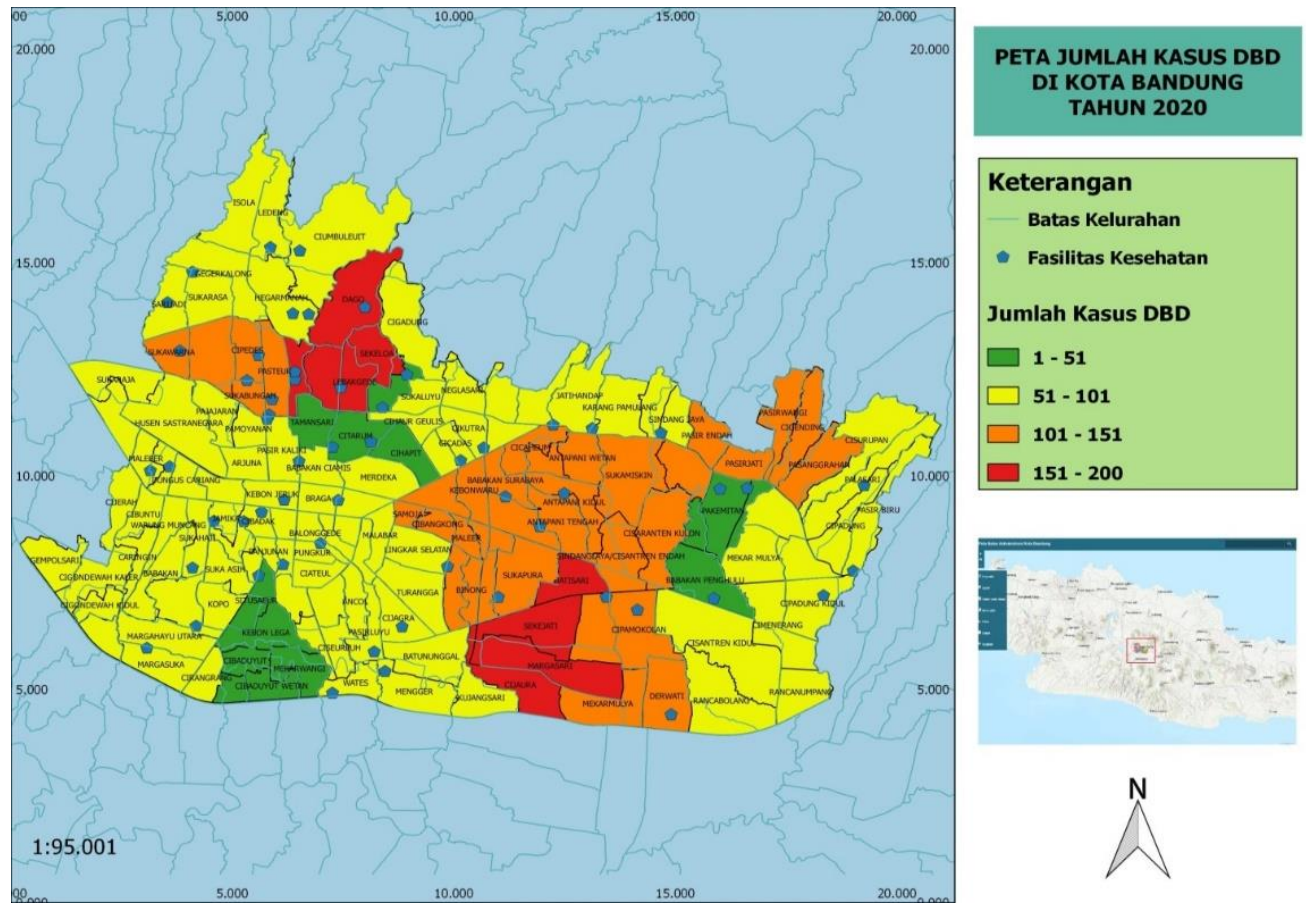

Gambar 4. Peta Sebaran Wilayah Kasus DBD Di Kota Bandung Tahun 2020

\section{Pembahasan}

Hasil proyeksi kasus DBD menggunakan microsoft excel menunjukan penurunan kasus DBD yang signifikan. Sedangkan proyeksi menggunakan metode exponential smoothing model holt's linear trend menujukan peningkatan kasus DBD. Artinya terdapat perbedaan dari dua metode yang digunakan. Hal ini kemungkinan disebabkan data yang digunakan untuk melakukan proyeksi hanya sedikit. Dalam penelitian ini tidak dapat membenarkan metode yang mana yang lebih efektif, karena banyak metode yang dapat digunakan dalam melakukan peralaman kasus. Penedapat peneliti bahwa model holt's linear trend yang menunjukan proyeksi kasus DBD di Kota Bandung, karena pada model ini memprediksi jumlah kasus berdasarkan jumlah kasus tiga tahun sebelumnya yang memang menunjukan peningkatan jumlah kasus, walaupun di tahun 2020 jumlah kasus menurun, akan tetapi tiga tahun sebelumnya jumlah kasus terus meningkat, jadi besar kemungkinan akan terjadi meningkatan kembali di beberapa tahun kedepan.

Pada umumnya terdapat algoritma-algoritma yang digunakan para peneliti untuk memprediksi suatu kasus permasalahan yaitu algoritma peramalan yang kemudian terbagi menjadi 2 yaitu algoritma peramalan subjektif dan algoritma peramalan objektif, algoritma peramalan subjektif merupakan model kualitatif, digunakan apabila data kuantitatif yang akurat sulit diperoleh, model ini tidak menggunakan pendekatan matematis hanya menggunakan intuisi saja. Sedangkan algoritma peramalan objektif memiliki dua model yaitu: model kausal dan model time series, model kausal lebih mempertimbangkan nilai sebuah variabel sebagai pengaruh dari banyak variabel lainnya, sedangkan model time series digunakan untuk melakukan pediksi masa depan menggunakan data historis. Algoritma juga terdiri dari beberapa macam seperti moving average, Exponential smoothing dan proyeksi trend. ${ }^{15}$ 
Penggunaan dua pendekatan ini tidak mengurangi ketajaman hasil analisis proyeksi (peramalan). Hal ini dilakukan untuk mengafirmasi pendapat bahwa teknik peramalan dapat dilakukan dari cara yang sederhana hingga dengan cara yang paling kompleks. Ditambah lagi dengan adanya teknologi disatu sisi berupa hardware maupun software komputer semakin memudahkan dan menyederhanakan cara proyeksi. Meskipun disisi lain, kesederhanaan dan kemudahan cara melakukan peramalan tidak mengurangi akurasi hasil proyeksi. ${ }^{16}$

Penelitian ini juga sejalan dengan penelitian di Jawa Barat tentang penentuan daerah rawan gizi berdasarkan analisis spatial. Persamaan kedua penelitian ini adalah sama-sama menggunakan pendekatan sistem informasi geografi (SIG) untuk mendapatkan hasil penelitian. Akan tetapi terdapat perbedaan mendasar pada tujuan kedua penelitian ini, yaitu sebelitian sebelumnya ini menggunakan metode analisis SIG untuk melakukan pengelompokan data dan overlay peta dengan cara union. Sedangkan penelitian ini menggunakan metode tabulasi data sekunder kemudian diolah dan dianalisis menggunakan metode exponential smoothing melalui dua pendekatan yaitu dengan aplikasi microsoft excel dan software SPSS.25 untuk mendapatkan hasil peramalan (proyeksi) 5 tahun kedepan. Artinya, fungsi SIG dalam penelitian ini digunakan mengolah data tersebut menjadi peta yang berfungsi sebagai informasi geografis, SIG tidak digunakan untuk analisis dan proyeksi kasus DBD. ${ }^{17}$

Melihat sebaran penyakit DBD berdasarkan kecamatan yang tujuannya adalah untuk dilakukan intervensi lebih lanjut berupa pencegahan dari faktor risiko DBD tersebut. Hasil analisis SIG menunujukan bahwa terdapat dua kecamatan dengan kasus DBD lebih dari 150 kasus yaitu Kecamatan Coblong dan Buah Batu. Nyamuk Aedes aegypti yang merupakan vektor utama penyakit DBD memiliki pola hidup didaerah panas sehingga menjadikan penyakit ini berkembang di daerah perkotaan. Faktor risiko penularan DBD adalah pertumbuhan penduduk perkotaan yang cepat, mobilisasi penduduk karena membaiknya sarana dan prasarana transportasi dan terganggu atau melemahnya pengendalian populasi sehingga memungkin terjadinya KLB. ${ }^{3}$

Penelitian ini sesuai dengan pendapat Aronoff (1989 dalam Halimah \&Suntin, 2020) bahwa Sistem Informasi Geografis (SIG) ialah sebuah sistem informasi berbasis komputer yang dapat digunakan untuk mengolah dan menyimpan data atau informasi geografis. SIG memiliki sebuah kemampuan untuk menghubungkan berbagai data pada suatu titik tertentu di bumi, menggabungkannya, melakukan analisa dan memetakan hasilnya. SIG berfungsi menyimpan data, mengolah data dan memetakan hasil kedalam visualisasi atau gambar model. ${ }^{12}$

Sebagian besar sebaran DBD di Kota Bandung adalah pada wilayah kuning yang artinya jumlah kasus berkisar 51 sampai dengan 100 kasus. Pada penelitian ini tidak dapat membuktian pola sebaran risiko tinggi di setiap Kecamatan. Penelitian lain yang dilakukan di Kota Banda Aceh menyatakan bahwa SIG yang dirancang mampu memetakan penyebaran penyakit DBD disetiap desa dan kecamatan yang fluktuatif dan tergolong tinggi. Software Quantum SIG yang digunakan mampu menghasilkan SIG yang menampilkan penyebaran DBD berdasarkan range dan kelas penyebaran DBD yang dihasilkan melalui perhitungan metode Sturges. ${ }^{7}$ Penelitian lain di Kabupaten Kendal yang menggunakan metode SIG untuk mengestimasi tingkat kerawanan DBD, menyatakan bahwa hasil dari analisis spasial SIG dapat menujukan daerah dengan tingkat kerawanan rendah dan sedang, meskipun dalam penelitian ini belum dapat menunjukan tingkat kerentanan terhadap penyakit DBD. ${ }^{18}$

\section{Kesimpulan}

Proyeksi jumlah kasus DBD di Kota Bandung pada periode 2021-2025 menggunakan metode microsoft excel secara umum mengalami penurunan sedangkan mengunakan metode exponential smoothing model holt's linear trend mengalami peningkatan. Berdasarkan data sekunder kasus DBD, 
maka pemetaan wilayah persebaran kasus DBD dilakukan di 30 Kecamatan Kota Bandung, terdapat dua Kecamatan dengan jumlah kasus sangat tinggi yaitu Kecamatan Coblong dan Buah Batu.

\section{Saran}

Perlu dilakukan pencegahan kasus DBD di seluruh wilayah Kota Bandung, karena setiap kecamatan yang ada di Kota Bandung berpotensi mengalami peningkatan jumlah kasus di 5 tahun kedepan. Serta perlu dilakukan penelitian lebih lanjut dengan membandingkan metode lain seperti Triple Exponential Smoothing Winter's untuk melihat proyeksi yang lebih akurat.

\section{Daftar Pustaka}

1. Wang W-H, Urbina AN, Chang MR, Assavalapsakul W, Lu P-L, Chen Y-H, et al. 2020. Dengue Hemorrhagic Fever-A Systemic Literature Review of Current Perspectives on Pathogenesis, Prevention and Control. J Microbiol Immunol Infect [Internet]. Available from: https://www.sciencedirect.com/science/article/pii/S1684118220300670

2. Wei H-Y, Shu P-Y, Hung M-N. 2014. Characteristics and risk factors for fatality in patients with dengue hemorrhagic fever, Taiwan, Am J Trop Med Hyg [Internet]. 2016;95(2):322-7. Available from: https://www.ajtmh.org/content/journals/10.4269/ajtmh.15-0905

3. Sutriyawan A, Aba M, Habibi J. 2020. Determinan Epidemiologi Demam Berdarah Dengue (DBD) Di Daerah Perkotaan: Studi Retrospektif. J Nurs Public Heal. 8(2):1-9.

4. Kemenkes RI. Profil Kesehatan Indonesia Tahun 2019 [Internet]. Jakarta: Kementerian Kesehatan Republik Indonesia; 2019. Available from: https://pusdatin.kemkes.go.id/resources/download/pusdatin/profil-kesehatanindonesia/Profil-Kesehatan-indonesia-2019.pdf

5. Kemenkes RI. Hingga Juli, Kasus DBD di Indonesia Capai 71 Ribu [Internet]. 2020. Available from: $\quad$ https://www.kemkes.go.id/article/view/20070900004/hingga-juli-kasus-dbd-diindonesia-capai-71-ribu.html

6. Dinas Kesehatan Kota Bandung. 2019. Jumlah Penderita Demam Berdarah Dengue Berdasarkan UPT Puskesmas di Kota Bandung [Internet]. Available from: http://data.bandung.go.id/dataset/jumlah-penderita-demam-berdarah-dengue-di-kota-bandung

7. Munandar YA, Ardian Z. 2018. Perancangan Sistem Informasi Geografis Pemetaan Penyebaran Demam Berdarah Dengue (DBD) di Kota Banda Aceh Pada Tahun 2014-2016. J INFORMATICS Comput Sci. 2018;4(1):16-22.

8. Novratilova S. 2018. Angka kejadian penyakit demam berdarah dengue di kabupaten sleman tahun 2016 kajian menggunakan sistem informasi geografis. J Inf Syst Public Heal. 2018;3(3):85-94.

9. Ristanto F, Kaunang WPJ, Pandelaki AJ. 2015. Pemetaan kasus demam berdarah dengue di Kabupaten Minahasa Utara. J Kedokt Komunitas Dan Trop. 2015;3(2).

10. Musfanto CP, Sumampouw OJ, Pinontoan OR. 2019. Sebaran Kejadian Demam Berdarah Dengue di Kota Manado Tahun 2016-2018. KESMAS. 2019;8(6). 
11. Muliansyah TB. 2016. Analisis Pola Sebaran Demam Berdarah Dengue Terhadap Penggunaan Lahan Dengan Pendekatan Spasial Di Kabupaten Banggai Provinsi Sulawesi Tengah Tahun 2011-2013. J Inf Syst Public Heal. 2016;1(1):47-54.

12. Halimah N, Suntin S. 2020. Proyeksi dan Pemetaan Wilayah Sebaran Balita Stunting Di Kota Makassar Berbasis Sistem Informasi Geografi (SIG). Promot $J$ Kesehat Masy. 2020;10(2):173-84.

13. Sutriyawan A. 2021. Metodologi Penelitian Kedokteran dan Kesehatan: Dilengkapi Tuntunan Membuat Proposal Penelitian. Bandung: PT Refika Aditama.

14. Alda R. 2009. Penerapan Metode Exponential Smoothing untuk Peramalan Penggunaan Waktu Telepon di PT. Telkomsel Drive3 Surabaya. Institut Teknologi Sepuluh November, Surabaya.

15. Kristianto RP, Utami E, Lutfi ET. 2017. Penerapan Algoritma Forecasting untuk Prediksi Penderita Demam Berdarah Dengue di Kabupaten Sragen. SEMNASTEKNOMEDIA ONLINE. 2017;5(1):1-2.

16. Yudaruddin R. 2019. Forecasting untuk Kegiatan Ekonomi dan Bisnis. RV Pustaka Horiz.

17. Fuada N, Muljati S, Hidayat TS. 2012. Penentuan daerah rawan gizi berdasarkan analisis spatial. National Institute of Health Research and Development, Indonesian Ministry.

18. Wijaya AP, Sukmono A. 2017. Estimasi Tingkat Kerawanan Demam Berdarah Dengue Berbasis Informasi Geospasial. J Geogr Media Inf Pengemb dan Profesi Kegeografian. 2017;14(1):40-53. 